Critical Rhythm 
VERBAL ARTS: STUDIES IN POETICS

Lazar Fleishman and Haun Saussy, series editors 


\title{
Critical Rhythm
}

The Poetics of a Literary Life Form

\author{
BEN GLASER AND \\ JONATHAN CULLER, EDITORS
}

Fordham University Press

NEW YORK 2019 


\section{Copyright $@ 2019$ Fordham University Press}

All rights reserved. No part of this publication may be reproduced, stored in a retrieval system, or transmitted in any form or by any means-electronic, mechanical, photocopy, recording, or any other-except for brief quotations in printed reviews, without the prior permission of the publisher.

Fordham University Press has no responsibility for the persistence or accuracy of URLs for external or third-party Internet websites referred to in this publication and does not guarantee that any content on such websites is, or will remain, accurate or appropriate.

Fordham University Press also publishes its books in a variety of electronic formats. Some content that appears in print may not be available in electronic books.

Visit us online at www.fordhampress.com.

Library of Congress Cataloging-in-Publication Data

Names: Glaser, Ben, editor. | Culler, Jonathan D., editor.

Title: Critical rhythm : the poetics of a literary life form / Ben Glaser and Jonathan Culler, editors.

Description: New York : Fordham University Press, 2019. | Series: Verbal arts: studies in poetics | Includes bibliographical references and index.

Identifiers: LCCN 2018028222| ISBN 9780823282043 (cloth : alk. paper)| ISBN 9780823282036 (pbk. : alk. paper)

Subjects: LCSH: Rhythm in literature. | Poetics-History-19th century. | Poetics-History-2oth century.

Classification: LCC PN1059.R53 C75 2019 | DDC 808.1-dc23

LC record available at https://lccn.loc.gov/2018028222

Printed in the United States of America

$212019 \quad 54321$

First edition 